\title{
HUMANITIES IN INDONESIA FOR A GLOBAL AGE
}

\author{
Anthony Reid ${ }^{1}$ \\ ${ }^{1}$ Australian National University \\ Email: anthony.reid@anu.edu.au
}

\begin{abstract}
The $70^{\text {th }}$ Anniversary provides an opportunity for reflection on the development of the Humanities in Indonesia, the achievements and the disappointments of a remarkable period. Indonesian Humanities scholars, and specifically those at UGM, have much to be proud of. They have built professional critical methods in a completely new language and context, without losing the critical approach to evidence. There have however been some disappointments and losses. Bahasa Indonesia's gain has been many other languages' loss. There is a danger that Humanities, in Indonesia as everywhere, may allow themselves to be restricted to a kind of heritage industry, preserving and coding the culture of 'us', as opposed to the complex interactions of the planet and beyond. The best way to counter the long-term decline of Humanities in the university may be the opposite, to embrace cultural diversity and interdependence.
\end{abstract}

Keywords: Humanities, Indonesia, Gadjah Mada University, Leiden, globalization.

\section{CONGRATULATIONS AND DEFINITIONS}

We are here to celebrate and reflect upon 70 years of achievement by UGM's Fakultas Ilmu Budaya. It has much to be proud of, in building professional critical methods in a completely new language and context, without losing the critical approach to evidence.

I am going to talk about 'the Humanities', or Humaniora, as what we do, because it is a venerable and universal term. Of course the Faculty was once called Literature (Sastera), and is now Fakultas Ilmu Budaya, which can be translated Faculty of Cultural Science or Cultural Studies. Cultural Studies is a more fashionable term than Humanities, implying the incorporation of film and other new media as the antique term does not. We have always needed to generate new terms to help us escape from words, associations and theoretical paradigms that trap us into the musty imagery of a bygone age. Professor Chua's paper is much better able to expand upon this concept and where it may be leading us.
However new terms are also limiting in a longer term perspective, because they are so firmly identified with a particular decade, replaced by a new concept with ever increasing frequency. Since I want to make some essentially historical points about the evolution of the Humanities, I will stick with that old-fashioned nomenclature. The term goes back to the European Middle Ages, to distinguish the study of humans and their cultural expression from the study of sacred religious texts - theology or divinity. It was then a breakaway from the older model, but over the last thousand years Humanities themselves have suffered the defection of ever more newly defined disciplines. What we are left with is I think the study of human expression originally in the written word, but latterly also in imagery, theatre, film, etc. Our work must be evidence-based, but not by reducing our questions to what can be tested experimentally.

So I am celebrating your achievement in the Humanities over 70 years, as especially impressive in comparative perspective. Most of the world's 
younger universities founded after World War 2, as both UGM and my own university, ANU, were, did not give priority to the Humanities, but to newer disciplines such as economics, sociology, political science, which believed themselves more 'scientific'. Because the older universities had been built around the Humanities, newer ones thought they had to be different and go with the times.

\section{THE DUTCH-INDONESIAN TRANSITION IN THE HUMANITIES}

Of course in Indonesia UGM rightly considers itself as in the old category, not the new. As a true 'university', in its original meaning of being a repository of universal knowledge across the spectrum, it must be Indonesia's second oldest since 1949. By dating its origins to 1946 Fakultas Ilmu Budaya can even make a case for being the oldest continuously operating humanities faculty, given the initially interrupted nature of UI. But UGM could not escape its times, or its background. The Dutch educational planners who introduced tertiary education to Indonesia might be seen as allergic to Humanities, which they thought would produce graduates who were not so much useful to the state as critical of it. Even more than other colonial powers, the Dutch favoured practical technical training of the people a modern state needed-hence the Technische Hogeschool [ITB] at Bandung (1920) for engineers, the Rechtshogeschool (1924) and Geneeskundige Hogeschool (1927) in Batavia, for lawyers and doctors respectively, and Faculteit van Landbouwwetenschap (IPB) in Bogor (1941) for agriculture.

In practice increasing numbers of Humanitiesoriented students were graduating from Dutchmedium high schools, while the kind of true university under discussion ever since the 1920 s would have had to include this crucial dimension. Even so the foundation of a Humanities faculty, Faculteit der Letteren en Wijsbegeerte (Faculty of Letters and Philosophy) in Batavia, was delayed as long as possible, until 125 students began in 1940, just in time to be closed by the Japanese two years later. C.C. Berg (already a Leiden professor) was appointed to the first chair in Javanese (initially with Malay), and A.A. Cense in 1941 to that in
Malay. ${ }^{1}$ This late start is a remarkable contrast with the Humanities-heavy university education begun by the British in India (three universities in 1857) and Burma (1920), the French in Indochina (1901), and the Spanish (1611) and Americans (1908) in the Philippines

Even in Yogyakarta, famously the cultural heart of the country, the Dutch planners chose to emphasize science. The senior high school (AMS) they established in the city in 1919 was for a science training (afdeling B), preferring Surakarta for the humanities including Javanese and Malay literatures. Romo Zoetmulder had to go to Solo to get his degree with C.C. Berg in Old Javanese. Only 16 years later, in 1935, did they establish an AMS-afdeling $A$ for literature also in Jogja, one of the routes for admission to the planned Faculty of Letters in Jakarta. This AMS did belatedly produce such pioneers as Dr Koentjaraningrat, Dr Soekmono and Dr Soepomo. In other words the establishment and success of a Fakultas Sastera in Yogyakarta in 1946 was truly novel, with no university tradition and very little senior high school background to build on. If I am not mistaken the first two professors and deans of that Faculty were Poerbatjaraka and Zoetmulder, neither of whom had much serious education in Yogyakarta - Poerbatjaraka got his $\mathrm{PhD}$ in Leiden without having any previous degrees, in fact.

There is a paradox here. While students in Indonesia were encouraged into technical fields, Dutch students trained in Holland for the colonial service (Binnenlandse Bestuur) studied not tropical agriculture, economics or medicine, as we might have expected, but Humanities. They studied Malay and Javanese texts, trying to master the high cultures of Indonesia. Leiden and Utrecht were of course old universities, with Humanities at the core. Classical texts and ancient learning were valued there, and the study of Biblical and European classical languages provided the precedent for expanding into knowledge about Indonesia. The best of these colonial scholars went on to doctorates at Leiden where they typically edited, translated and published a classical text. Even B.J.O Schrieke, who famously pioneered the teaching of sociology at the Law School in Batavia, had done his dissertation at Utrecht on a $17^{\text {th }}$ century Javanese religious text. ${ }^{2}$ It would be a 
hard sell today for a public servant or development expert. The importance and relevance of the Humanities, in other words, was exaggerated in Holland but minimized in Indonesia.

I love these studies of Indonesian texts because they provide the historian with powerful Indonesian voices to begin to balance the huge weight of surviving European written sources. Nevertheless, looking back 70 years at the way the Humanities developed in Indonesia, one has to wonder whether Dutch strength in Indonesian literatures may paradoxically have been an obstacle to their development in Indonesian universities. In 1940, at the peak of these studies, there were at least twenty academically-trained (typically with Leiden $\mathrm{PhDs}$ ) specialists on Indonesian languages and literatures on the government or Bible Society payroll, publishing on such languages as Javanese (Pigeaud, Tjan Tjoe Siem, Poerbatjaraka and Berg), Balinese, Sundanese, Makassarese, Menadonese, Toraja, Batak, Acehnese and Sumba. Yet only Tjan Tjoe Siem, Poerbatjaraka and Hoessein Djajadiningrat considered themselves (or were considered) 'Indonesian' enough to remain in the country after the mid-century upheavals, and none of them were actively teaching. The degree structure for Indonesian letters established in Jakarta, like that at Leiden, insisted on two years of Indian and Islamic languages and cultures before tackling the Indonesian ones in the third year. ${ }^{3}$ The required skills in Dutch and other European languages, Sanskrit and Arabic (before even considering the Indonesian ones), and the relative abundance of Dutchmen possessing them, made it very difficult for Indonesian literati of the old school to transition to the new academic one.

Despite the failure to build a strong Humanities background in Indonesia, the centrality of the Humanities in Holland (and to a lesser extent France, Britain and Germany) was very important for the development of the study of Indonesian cultures. The first professor in Holland (or probably anywhere) with an interest in Indonesian languages was Adrian Reland, son of a Protestant clergyman, who as a teenage student at Utrecht had already learned Latin, Hebrew, Chaldean and Arabic. He was appointed professor of Oriental languages at Utrecht in 1701, and became fascinated by Malay and Javanese writings, having them sent from
Java in the early 1700s. He was among the first to draw attention to the common elements in Malay and Polynesian languages, in $1708 .{ }^{4}$ When chairs of Malay and Javanese were established in the $19^{\text {th }}$ century, it was again an extension of the way universities moved on from Greek and Hebrew to other Middle-Eastern languages of relevance to scriptural studies.

Curiously this 'orientalist' tradition reached its peak in the first years of Indonesian independence, as it was mortally wounded. In the years 1946-68 the KITLV membership and its publishing output were greater than ever, with over 50 monographs on language and culture. In 1968 the Indonesian Department at Leiden baosted Berg, Uhlenbeck, Teeuw, Anceaux, Roolvink, Ras and Noorduyn, and could teach half a dozen Indonesian languages and literatures. There were chairs of Sundanese and Old Javanese as well as the long-standing ones in Javanese and Malay. Yet there were virtually no students - only three Dutch students completed the PhD in this period (Ras, Brakel and C.L. Voorhoeve). ${ }^{5}$ The rupture of relations in 1958 prevented Indonesians from studying in Holland, and it was only in Malaysia/Singapore and Australia (Peter Worsley and Stuart Robson graduated Leiden in 1971 and 1972) that students were found to carry on the tradition.

Indonesian language and literature study in Holland did not long outlast that rich post-war generation of professors. The tradition was kept alive after the restoration of relations through a 'Joint Indonesian-Dutch Programme of Indonesian Studies', funded by Netherlands foreign aid in 197592. Dutch professors, and even some Australian imports, found positions teaching Indonesian students in languages and literatures, trying to overcome the deep rupture in the transition from Dutch to Indonesian leadership in the Humanities. Many useful dictionaries of Indonesian languages were produced under this program, but after 1992 the emphasis of Netherlands aid shifted to more 'modern' and popular areas.

The tradition of maintaining the academic study of what are now called the 'regional' languages and literatures of Indonesia can be considered finished in Holland. ${ }^{6}$ Germany and France have preserved a few dedicated positions, because they have better preserved a culture of 
research as a justification for academic positions (as did the communist countries with their Oriental Institutes). For a time Australia was the best hope outside Indonesia for continuing the emphasis. When Departments of Indonesian Studies were established at Sydney, ANU and Monash in the late 1950s, textual Humanities scholars in the Leiden tradition were appointed to each of them - in Sydney van Naerssen, followed by Peter Worsley; at ANU Tony Johns (1958) supported by UGM scholars Dr Soebardi (1961), Dr Soewito-Santoso (1964) and Dr Supomo (1971); $;^{7}$ at Monash Cyril Skinner, followed by Stuart Robson. But since David Hill retired from Murdoch University at the end of 2015, discouraged by the trend, only two or three active researchers on Indonesian literatures hold university jobs in Australia (film and popular culture may be doing better).

Student numbers now determine academic positions, and few scholars of Indonesian literatures old and new can deliver this. They are sustained if at all by teaching Bahasa Indonesia. I helped conduct a review of KITLV in Leiden in 2011, thinking my job was to defend this wonderful resource of expertise and materials for Indonesian textual study. But by then there was nobody left to fight for in terms of expertise. Our report piously said that this baton should be passed to Indonesia, the country with the central responsibility for preserving and studying its literary heritage. Universities like UGM, however, also find that old literatures are no way to attract undergraduate students. This is part of the retreat of Humanities more generally, to which I will return. Study of the classics can no longer be maintained by the Academy as simply a 'good thing', a necessary part of our civilization.

\section{UGM HAS ACHIEVED MUCH, WHILE RETAINING SOME CRITICAL DISTANCE}

Given this difficult background, UGM Humaniora has contributed mightily to building a literature and a critical culture in the new medium of Indonesian. I don't know all your famous graduates, but I believe W.S. Rendra, Umar Kayyam, and Kuntowijoyo all graduated from the old Fakultas Sastera. If true, this is impressive by any international standards - studying literature critically in the academy is often thought to be an obstacle to creative writing.

Of course it is the History Department, Jurusan Sejara,h I know best, having intersected over the years since first being attached to it under Prof Sartono Kartodirdjo's guiding hand in 1972. Prof Sartono himself, and his key students Adri Lapian, Teuku Ibrahim Alfian, Abdurrahman Surjomihardjo and others, set a high standard of critical history. If we look around the world at other new post-revolutionary moments when one dominant culture was rejected and a new one invented, the dangers of this process become clear. I spent a year in Berlin recently and paid some attention to the post-1918 and post 1945 revolutions in Central Europe. When Czechoslovakia, Slovenia, Croatia and even Poland obtained their freedom and rejected the German-speaking critical culture which had been built up in their universities, museums and scholarly institutes under Prussian and Austrian influence, they had suddenly to invent a new national culture in their Slavic languages in a way rather similar to Indonesia. Korea and Viet Nam may be the closest Asian analogies, in their rejection of Japanese and French academic cultures respectively after 1945 . The temptation of the Humanities scholars is then to encourage and try to ride the youthful identity politics into a new kind of fundamentalism. Having performed heroic feats in their youth of rescuing and reinventing inspiring texts and events of the past, they can as they age make these into an orthodoxy rather than a liberation, endangering even the fragile sprouts of critical thinking that had been present under the old regime.

India, the Philippines and Singapore never entirely abandoned the intellectual culture of the colonial language, English, partly of course because it became the global academic language. But we should compare Indonesia not with these non-revolutionary transitions to independence, but to Korea and Viet Nam, where the attempt was made, as in Indonesia, to invent a new academic culture in a language that had not sustained one before. In comparison with these cultural revolutions, Indonesian Humanities have not done too badly at retaining a critical culture that allows a diversity of opinion and culture. 
U.I. of course has enjoyed many advantages by being at the centre and close to government. More money flowed their way, and more international contacts. But Gadjah Mada has played a crucial role by not being at the centre. Its scholars were not as prone as those of UI to be tempted by power and influence, with the rapid rises and falls that often entails. I am not competent to judge how this factor might have worked in literature, though I do wonder how far the presence in Jakarta of first Balai Pustaka, then the Japanese-sponsored cultural institute (Keimin Bunka Shidosho), and finally the Indonesian Ministry of Culture may have promoted orthodoxy and restricted dissident ideas there. I suspect only Jakarta could have produced a figure like H.B. Jassin, Paus Sastera Indonesia, the "Pope" or arbiter of what was right in Indonesian literature. In contrast, perhaps only Jogja and UGM could have produced a wonderful subversive like Rendra.

I am more confident in History, and the contrast between UGM's Sartono Kartodirdjo and UI's Nugroho Notosusanto. Nugroho, like Jassin, was at the political centre, heavily involved in its polarised politics. Against the PKI-backed vision of 1945-9 as an unfinished, incomplete revolution, he charted a military version of Indonesian history, in which armed struggle was always at the centre, the Army was its indispensable institution, and the upheavals of 1945-9 represented not a revolution but a war of independence. Once the Army was in power after 1966, Nugroho gave the military the kind of history they wanted, and was rewarded by being made Minister of Education and Rector of UI (1983-6). As Jogja historians know well, Sartono was unhappy with the way Nugroho pushed through his version of events in Volume 6 of Sejarah Nasional Indonesia and maintained a dignified distance from the militarised national history it represented. ${ }^{8}$ In doing so I believe he gave more space for UGM historians to be truthful to themselves and their profession.

\section{THERE HAVE ALSO BEEN DISAPPOINTMENTS}

In an age of global comparisons, Indonesian Humanities have not fared well in the world rankings for publications, citations and so forth. The roughly 24,000 books published in Indonesia per year recently are fewer than the output of Viet Nam with a third the population; or of Taiwan, Australia or Argentina with about a tenth the population. ${ }^{9}$ The story gets worse when we look at scholarly publications. Over the period 1996-2010 Indonesia's 13,000 published scientific documents as measured by SCImago placed it below Kenya and Nigeria, and far below neighbours Thailand, Malaysia and Singapore with their much smaller populations. In the 2008 Social Science Index, only $12 \%$ of research published on Indonesia, much of which would be classified as Humanities, was published by authors in Indonesia - a proportion again far below neighbours. ${ }^{10}$

Indonesia was the featured country ('guest of honour') at the Frankfurt book fair in 2015, more, it appears, to ensure that the $50^{\text {th }}$ anniversary of the 1965 massacres did not pass unnoticed than for interest in Indonesian literature in itself. One of the discussions of the event called Indonesia 'The island that literature forgot." ${ }^{11}$ I had found at Berlin's biggest bookstore in 2012 that there was not a single Indonesian work in translation in its depot. UNESCO data on translations into European languages in the period 1995-2005 showed Indonesian was not even in the top ten Asian languages being translated, although Vietnamese, Tibetan and even Kurdish were. ${ }^{12}$ There was a scramble to find translators who could deliver with a year's deadline enough translations in German and English to make the Frankfurt guest of honour status meaningful. Those defending the choice had to admit that that Indonesia does not have a 'book culture'. Goenawan Mohammad, chairman of the national committee for Indonesia, noted in his speech that "We Indonesians are more sociable and love a good dose of noise. Aside from that, of course, we don't have long winters for sitting inside to read 'War and Peace'."

John McGlynn also noted that part of the problem is the lack of real understanding of literature and creative writing in the school system. "Literature as it's known in the West isn't taught at schools. Children do learn when Jane Austen lived, but they don't usually read any of her books. So it's actually astounding that there are outstanding authors here. After all, where could they to have learned to write? Certainly not at school." ${ }^{13}$

This situation is endemic and long-term. It is 
not the fault of Humanities scholars in UGM or other universities. It could even be argued that the fact (according to those UNESCO statistics) that so much more is translated into Indonesian than out of it, more than into Hindi, Bengali or Vietnamese, ${ }^{14}$ is an index of the total triumph of Indonesian as against colonial or other languages. There are however, some other causes of concern in the study of Indonesian cultures.

Firstly, the triumphant rise of Indonesian has meant the rapid decline of Javanese and all other regional languages as vehicles for creative writing and analysis. This is a much bigger issue than the universities, but it is a fact Humanities scholars must face and respond to. The heyday of the larger regional languages was the 1920s, when newspapers sprouted like mushrooms in Javanese, Sundanese, Batak, Bugis and Balinese, and filled their columns with short stories and poetry as well as news. The smaller languages and dialects without written expression did not fare so well even then, and their steady disappearance is a matter of concern especially for the linguists. What is the role of the University in this situation of rapid erosion of writing traditions? It cannot keep a dying tradition alive, but it can provide a critical apparatus of dictionaries, grammars and edited texts. With that comes a certain status, which can be very important for survival.

Javanese as a spoken language is not going to die anytime soon. With some 80 to 100 million speakers it is the $12^{\text {th }}$ most spoken language in the world as mother tongue, but vastly less studied in the university than other 'big' languages. For over a century, up to 2008, the only chair in Javanese in the world was at Leiden, and briefly the Jakarta offshoot described above. In 2008 Ben Arps' chair was combined with that for Malay/Indonesian, so that he became the Professor of 'Indonesian and Javanese Language and Culture'. When he retires it will be a battle to have even a chair of Indonesian. Javanese and Balinese survived rather longer as viable taught languages in Australian universities, but were never institutionalised with a chair of Javanese. George Quinn and Amrih Widodo continued to teach Javanese to small classes at ANU until last year, but that has stopped. It is more than ever obvious that teaching and research on Indonesian languages and literatures (beyond Indonesian) can only survive in Indonesia. Universities such as UGM can do more, but will always struggle to defend the small classes that go with low employment expectations. There need to be some state-funded dedicated Institutes for languages and literatures, like a plural version of the Dewan Bahasa dan Pustaka in Malaysia.

The second disappointment, or at least surprise, is that the locus of serious scholarship on Indonesia has not become Bahasa Indonesia and Indonesian institutions. My generation of Indonesia scholars thought that as foreigners we were a transitional group, keeping the flame alive for a while between colonial scholarship and the new local scholar generation that would take over. Ben Anderson in the 1980s optimistically announced as one of the great trends of the day the "indigenization" of important work on the region (his examples being in history and politics). His most convincing example of the way critical new ideas were being written by Southeast Asians in the vernacular were Thai historians - Chatthib Nartsupha, Thaemsuk Nummanon and Nidhi Aeusrivongse -energised by the student uprisings of the 1970s. For Indonesia he tentatively proposed Burhan Magenda and Onghokham (though I think their most serious work was in English), but found most worthy of reading and recommending to others then-banned authors well outside the university establishment -Pramoedya Ananta Toer and the 1970s student leader Heri Achmadi - not academics at all. ${ }^{15}$

As so often, Ben was interesting but wrong. He stated provocatively what I think we had all expected. This transition kept being just out of reach, until now one begins to wonder if the tide has actually turned against serious publishing in Indonesian. Instead of indigenization, globalization has brought us a kind of homogenization, where academics are judged by what gets published and cited in high-impact journals - mostly in English.

Another disappointment, much remarked on at the $50^{\text {th }}$ anniversary, is the response to $1965-6$. Having never endangered my own life or career by speaking out boldly on behalf of an unpopular truth, I cannot presume to judge the courage of my fellow-historians. But let me simply express some surprise that it has taken so long for us all to correct the silences and distortions of the Suharto years. 
Indonesians of my age lived through 40 exciting, relatively open, but dangerous and chaotic years full of hardship after 1945, followed after 1966 by 30 years of oppression but rising security and prosperity. It is understandable that people kept their heads down after hundreds of thousands were killed because they were thought to have the wrong ideas or loyalties, and the army placed itself above the law to arrest, torture or kill anyone who stepped out of line. I always remember a Medan taxi-driver I met in the 1980s, who when he learned that I taught history fell silent for a while. Then he quietly began to tell of the love he conceived for history in his Medan high school, fired by a passionate teacher who opened his mind to the world. Passionate teacher opened up his mind to the world. Then in October 1965 he disappeared, and was not seen again. 'I learned,' he said, 'that it was dangerous to be smart. Lebih baik bodoh saja, dan selamat.' The great ideological reversal began with the schools, and made it very hard for the schoolchildren of the 1970s and ' 80 s to think of 1965-6 except as a triumph over 'evil'.

The surprise for me was that the fall of Suharto did not snap the oppressive orthodoxy and release a great surge of creativity and critical thinking. I remember my surprise when watching TV coverage in Canberra of Suharto's resignation with some Indonesian students. They did not seem particularly excited, as I remembered Thai students had been when their dictator fell in 1973. Thirty years had evidently been long enough to seem to 'normalize' the abnormal horrors of 1965-6. History-writing appeared to change even more slowly than public perceptions. I salute those historians and others who have accepted a responsibility to open this dark chapter to public light. An honest and open society requires an honest and open history, and progress towards this goal, however slow, has been positive.

Finally, there appears to me to have been a contraction of scope, though here again I know too little to speak of anything but history. I became a historian because I wanted to understand how the world worked, and the historians seemed to explain that better than the economists or political scientists. They described not what should happen but what did happen as a result of the great upheavals of the world. But as I visit the world's history departments today there are not so many, including my own, that would deliver that. At UGM when I was enquiring recently what was taught and studied, somebody pulled Ibrahim Alfian's 1950s skripsi off the shelf, devoted to the Potsdam Agreement between Stalin, Churchill and Roosevelt after World War II. The comment was - "no more - we don't allow people to write on anything but Indonesia now."

For the first half of the 70 years we are celebrating, poverty, poor resources and political instability provided abundant reasons why this focus should occur. Libraries could barely cover Indonesia's own meagre publications. Students could hardly cope with English let alone any other foreign language. And there was much to be done at home in building an acceptable Indonesian history.

The nationalism of the times was not I think the cause of this shrinking of horizon, but it may have legitimated it in the minds of students. It went with an understandable but tragic reduction of Indonesia itself to that modern part of the country that expressed itself in Indonesian. I want to quote here the most celebrated of contemporary Algerian writers, Kamel Daoud, who of course writes in Arabic but accepts Algeria's many literary pasts. That specifically includes Albert Camus, one of the greatest writers of French literature, who lived in Algeria and wrote his most famous novel about it.

"[Camus] was an Algerian writer. My own 'Algerianess' is not exclusive and does not exclude others: I assume everything that enriches me, including the monstrous wound of colonization. Camus is Algerian because Algeria is larger and older than French Algeria, Ottoman Algeria, Spanish or Arab Algeria. ${ }^{16}$

If we were to transpose that quote to an Indonesian setting, would it read something like this:

Eduard Douwes Dekker adalah penulis Indonesia. KeIndonesiaan-kutidak eksklusif dan tidak keluarkan orang lain. Saya mengaku apa saja yang memperkayakan saya, termasuk luka ngeri kolonialisme. Douwes Dekker adalah penulis Indonesia karena Indonesia lebih besar dan lebih tua 
daripada Indonesia Belanda, Indonesia Majapahit, Indonesia Hindu-Buddha, Indonesia Islam atau Indonesia Republik.

Today the restriction of focus in our teaching is both unnecessary and dangerous. Unnecessary because the internet makes the world's literature accessible to all. Dangerous because it risks making Humanities part of the problem, a bastion of identity, heritage, of 'us'-ness. In this globalising world, if the Humanities survive only as the keepers of the flame of national culture, students will see it as a quaint anachronism, not the way to a job or an understanding of the modern world.

\section{Humanities already are in a long-term decline, because:}

1. university education no longer automatically gets you a job as part of a small elite. Since a large proportion of young people now go to university, students have to calculate which kind of degree will get them a job. Computing, Business studies, communication, law, medicine, engineering may look more promising.

2. In the longer term, the Humanities have been in decline for centuries. In both Christian and Islamic traditions, learning was for a thousand years a matter of training religious specialists, priests and ulama. By definition humanities were the centre of academic life - theology, philosophy, and the languages essential to reading the scriptures themselves and the massive tradition of learning built around them. This meant Greek and especially Latin in the Christian universities, Arabic and some Persian in the Islamic. This older pattern at least forced students to get beyond their own heritage to wrestle with alien languages and concepts. Nationalism shifted the focus firmly to the national culture, though it also encouraged the social sciences more than the humanities. The utilitarian pragmatism of our own age shifts the focus of students further towards what seems likely to produce a job.

If we allow the Humanities to become the study of our own cultural roots as a nation or people, we are in danger of playing a much reduced role, essential only for a few people who staff museums, libraries, publishing houses, the heritage industry and tourism.

My own conviction is that we flourish as faculties only insofar as we can make ourselves attractive to students as public intellectuals, creative writers, and inspiring lecturers. In a global age, that means understanding how our own literature, history, or culture fits into the major global trends. As a Faculty and a profession we need to move confidently from the national to the global, transcending the ever-narrowing road of boosting national identity and heritage to explaining a complex world to our students. We need to teach the world's more important languages and literature, and address history, pre-history or deep history in conjunction with science, religion and culture on a global scale.

\section{Endnotes}

1 C.D. Grijns, 'Andries Teeuw: Bujangga Wredatama,' in A Man of Indonesian Letters: Essays in Honour of Professor A. Teeuw, ed. C.M.S. Hellwig and S.O. Robson (Dordrecht: Foris for KITLV, 1986), p. 3.

2 B.J.O. Schrieke, Het Boek van Bonang (Published Leiden dissertation, 1916). This pioneering work was more fully edited by G.W.J. Drewes as The Admonitions of Seh Bari: A $16^{\text {th }}$ century Javanese Muslim text attributed to the Saint of Bonan, reedited and translated with an introduction (The Hague: Martinus Nijhoff, 1969).

3 Grijns 1986, pp. 1-3.

4 Hadriani Relandi Dissertationum miscellanearum, 3 volumes (

5 Grijns 1986, pp. 8-9.

6 It seems unlikely there will be a successor to Ben Arps, who now combines the historic chairs of Malay/Indonesian and Javanese at Leiden.

7 Anthony Reid, 'Indonesian Studies at the Australian National University: Why so late?' Review of Indonesian and Malaysian Affairs 43, no.1 (2009), pp.51-74.

8 Marwati Djoened Poesponegoro and Nugroho Notosusanto (ed.), Sejarah Nasional Indonesia 
(Jakarta: Balai Pustaka for Departemen Pendidikan dan Kebudayaan, 1977, republished 1981-3, 1984, 1992, 2008).

9 https://en.wikipedia.org/wiki/Books_published per_country_per_year consulted 11-2-2016.

10 Scott Guggenheim, 'Indonesia's Quiet Springtime: Knowledge, Policy and Reform,' in Anthony Reid (ed.) Indonesia Rising: The Repositioning of Asia's Third Giant (Singapore: ISEAS Publications, 2012), pp. 144-5.

11 Wayan Sunarta, 'The island that literature forgot: Indonesian literature at the Frankfurt Book Fair'; https://en.qantara.de/content/indonesian-literatureat-the-frankfurt-book-fair-the-island-that-literatureforgot.

12 http://portal.unesco.org/culture/en/ files/41748/13390726483 Translation trends_1990_2005_Dec_2010.pdf/ Translation\%2Btrends\%2B1990_2005 De c \% 2 B 2010 . p d f.

13 Interviewed by Deutsche Welle at http://en.qantara. $\mathrm{de} /$ content/literature-in-indonesia-a-land-withoutreaders.

14 Indonesian fared better as a target language for translations from other languages at $40^{\text {th }}$ in the world, ahead of other South and Southeast Asian languages (most of which had greater access to writing in English) but below such languages as Icelandic and Welsh. http://www.unesco.org/xtrans/ bsstatexp.aspx? crit $1 \mathrm{~L}=4 \& n$ Typ $=\min \&$ top $N=50$

15 Benedict Anderson, 'Politics and Their Study in Southeast Asia,' in Southeast Asian Studies : Options for the Future, ed. Ronald A. Morse (Lanham/New York: University Press of America for the Wilson Center, 1984), pp.41-51.

16 Kamel Daoud [author of Meursault, contre-enquête (English trans as The Meursault Investigation), as cited by Claire Messud, 'The Brother of the "Stranger", NYReview 22 October 2015, p.56

\section{REFERENCES}

Anderson, Benedict (1984) 'Politics and Their Study in Southeast Asia,' in Southeast Asian Studies: Options for the Future, ed. Ronald A. Morse, Lanham/New York: University Press of America for the Wilson Center.

Drewes, G.W.J. (1969). The Admonitions of Seh Bari: A $16^{\text {th }}$ century Javanese Muslim text attributed to the Saint of Bonan, re-edited and translated with an introduction, The Hague: Martinus Nijhoff.

Grijns, C.D. 'Andries Teeuw (1986). Bujangga Wredatama,' in A Man of Indonesian Letters: Essays in Honour of Professor A. Teeuw, ed. C.M.S. Hellwig and S.O. Robson, Dordrecht: Foris for KITLV.

Guggenheim, Scott (2012). 'Indonesia's Quiet Springtime: Knowledge, Policy and Reform,' in Anthony Reid (ed.) Indonesia Rising: The Repositioning of Asia's Third Giant (Singapore: ISEAS Publications.

Messud, Claire, "The Brother of the "Stranger", NYReview 22 October 2015, p.56.

Poesponegoro, M.D., and Nugroho Notosusanto (ed.) (2008). Sejarah Nasional Indonesia (Jakarta: Balai Pustaka for Departemen Pendidikan dan Kebudayaan, 1977, republished 1981-3, 1984, 1992, 2008.

Reid, Anthony (2015). 'Indonesian Manuscripts in the Vatican Library,' in Southeast Asia Library Group Newsletter, no. 46: http://www.sealg. org/Newsletter2014.pdf.

'Indonesian Studies at the Australian National University: Why so late?' in Review of Indonesian and Malaysian Affairs 43, no.1

Schrieke, B.J.O. (1916), Het Boek van Bonang (Published Leiden dissertation).

Sunarta, Wayan (2015). 'The island that literature forgot: Indonesian literature at the Frankfurt Book Fair'; https://en.qantara.de/content/ indonesian-literature-at-the-frankfurt-bookfair-the-island-that-literature-forgot.

\section{OTHERS}

ht t p : / / portal.unesco.org/culture/en/ files/41748/13390726483Translation trends_1990_2005_Dec_2010.pdf/ Translation\%2Btrends\%2B $1990 \quad 2005$ Dec \% 2 B 2010 .pdf.

http://en.qantara.de/content/literature-in-indonesia-aland-without-readers.

http://www.unesco.org/xtrans/bsstatexp. aspx? crit $1 \mathrm{~L}=4 \& \mathrm{n}$ Ty $\mathrm{p}=\mathrm{min} \& \mathrm{t}$ o $\mathrm{pN}$ $=50$ 